\title{
Further evidence for heritability of an epimutation in one of 12 cases with MLH1 promoter methylation in blood cells clinically displaying HNPCC
}

\author{
Monika Morak ${ }^{1,2}$, Hans Konrad Schackert ${ }^{3}$, Nils Rahner ${ }^{4}$, Beate Betz ${ }^{5}$, Matthias Ebert ${ }^{6}$, \\ Constanze Walldorf ${ }^{4}$, Brigitte Royer-Pokora ${ }^{5}$, Karsten Schulmann ${ }^{7}$, \\ Magnus von Knebel-Doeberitz ${ }^{8}$, Wolfgang Dietmaier ${ }^{9}$, Gisela Keller ${ }^{10}$, \\ Brigitte Kerker $^{1}$, Gertraud Leitner ${ }^{2}$ and Elke Holinski-Feder ${ }^{*}, 1,2$

\begin{abstract}
${ }^{1}$ Department of Internal Medicine, Campus Innenstadt, University Hospital of the Ludwig-Maximilians-University, Munich, Germany; ${ }^{2}$ Center of Medical Genetics, Munich, Germany; ${ }^{3}$ Department of Surgical Research, University of Dresden, Dresden, Germany; ${ }^{4}$ Institute of Human Genetics, University of Bonn, Bonn, Germany; ${ }^{5}$ Institute of Human Genetics, Heinrich-Heine University Düsseldorf, Düsseldorf, Germany; ${ }^{6}$ Department of Medicine II, Klinikum rechts der Isar, Technical University, Munich, Germany; ${ }^{7}$ Medical Department, Ruhr-University Bochum, Bochum, Germany; ${ }^{8}$ Department of Molecular Pathology, Institute of Pathology, University of Heidelberg, Heidelberg, Germany; ${ }^{9}$ Institute of Pathology, University of Regensburg, Regensburg, Germany; ${ }^{10}$ Institute of Pathology, Technical University, Munich, Germany
\end{abstract}

Germline mutations in mismatch repair (MMR) genes, tumours with high microsatellite instability (MSI-H) and loss of MMR protein expression are the hallmarks of HNPCC (Lynch syndrome). While somatic MLH1 promoter hypermethylation is generally accepted in the tumorigenesis of sporadic tumours, abnormal MLH1 promoter methylation in normal body cells is controversially discussed as a mechanism predisposing patients to HNPCC. In all 94 patients suspected of HNPCC-syndrome with a mean age of onset of $\mathbf{4 5 . 5}$ years, MLH1-deficiency in their tumours but no germline mutation, underwent methylation-specific PCRscreening for $\mathrm{MLH} 1$ promoter methylation. In peripheral blood cells of 12 patients an MLH1 promoter methylation, in seven informative cases allele-specific, was found. Normal colonic tissue, buccal mucosa, and tumour tissue available from three patients also presented abnormal methylation in the $\mathrm{MLH} 1$ promoter. The heredity of aberrant methylation is questionable. Pro: $M L H 1$ promoter methylation was found in a patient and his mother giving evidence for a familial predisposition for an epimutation in $M L H 1$. Contra: a de novo set-up of methylation in one patient, a mosaic or incomplete methylation pattern in six patients, and no evidence for inheritance of $M L H 1$ promoter methylation in the remaining families. Our findings provide strong evidence that $\mathrm{MLH1}$ promoter methylation in normal body cells mimics HNPCC and constitutes a pathogenic pre-lesion in $M L H 1$. The identification of hypermethylation as an epigenetic defect has important implications for surveillance recommendations, as these patients should be treated like Lynch syndrome patients, whereas the heritability of methylation is still under investigation. European Journal of Human Genetics (2008) 16, 804-811; doi:10.1038/ejhg.2008.25; published online 27 February 2008

Keywords: MLH1; HNPCC; methylation; transmission; epimutation

*Correspondence: Dr E Holinski-Feder, Center of Medical Genetics, Bayerstrasse 3-5, 80335 Munich, Germany.

Tel: + 49893090886 0; Fax: + 49-89-3090 88666

E-mail: elkeholinski-feder@t-online.de

Received 11 September 2007; revised 31 December 2007; accepted 17 January 2008; published online 27 February 2008
Introduction

The hereditary non-polyposis colorectal cancer (HNPCC) syndrome is a familial predisposition to early-onset colorectal cancer (CRC) and tumours of the endometrium, stomach, small intestine, hepatobiliary system, ureter, renal pelvis, 
ovary, brain and skin (MIM No 114500). ${ }^{1}$ Germline mutations in the DNA mismatch repair (MMR) genes MLH1, MSH2, MSH6 or PMS2 are frequently found in combination with high microsatellite instability (MSI-H) and loss of MMR protein expression in tumours.

Suspicion of HNPCC is raised according to the Amsterdam criteria $^{2,3}$ or the less stringent Bethesda guidelines. ${ }^{4} \mathrm{MMR}$ deficiency due to loss of MLH1 in tumour tissue may be due to a germline mutation - but may also result from gene inactivation or silencing by DNA methylation or promoter mutation.

Methylation of cytosines in single $\mathrm{CpG}$ dinucleotides located in the promoter region of the MLH1 gene can epigenetically modify gene expression. ${ }^{5,6}$ The MLH1 CpG islands D and B/C (Figure $1 \mathrm{~b}$ ) are normally unmethylated ${ }^{7}$ while biallelic hypermethylation in the tumour tissue was found to be a causative mechanism for $15 \%$ of sporadic endometrial, ${ }^{8,9}$ gastric $^{10,11}$ and colorectal ${ }^{10,12-14}$ cancers showing MSI-H and immunohistochemical (IHC) MLH1-deficiency.

The transcriptional activity of the MLH1 promoter is strongly dependent on two CAAT boxes at c.1-282 and c. $1-145 \mathrm{bp}^{15}$ and on transcriptional enhancers in a region from c.1-250 to c.1-151 bp ${ }^{16}$ (Figure 1a). Another possibility for silencing would be promoter mutations, which have so far not been discovered. ${ }^{16-18}$

The CpG island methylator phenotype (CIMP) describes the hypermethylation of many $\mathrm{CpG}$ islands and the silencing of multiple genes, which is a result of the imbalance between methylation protection and de novo methylation activity. ${ }^{19,20}$ CIMP cancers include a majority of tumours with sporadic MMR deficiency through hypermethylation of the MLH1 promoter, but also include tumours without microsatellite instability. ${ }^{21}$

Besides methylation of the $M L H 1$ promoter in tumour cells, epigenetic silencing of MLH1 in normal body cells is discussed as a novel predisposition to MLH1 deficiency and CRC. Eleven cases of hemiallelic hypermethylation in the $M L H 1$ promoter region in peripheral blood of patients with early-onset of CRC or HNPCC-associated endometrial cancer have been reported in the literature. ${ }^{22-27}$

We add the so far largest number of a further 12 patients to this list, which not only helps to prove that aberrant methylation in the MLH1 promoter is an alternative pathomechanism for the HNPCC phenotype but also helps to better define the specific clinical features of these cases, including heritability. Furthermore, this is the second report of a maternal transmission of an MLH1 promoter methylation, excluding a de novo methylation by chance and pointing towards a familial and heritable predisposition for an epimutation in MLH1.

\section{Materials and methods \\ Patients and material}

Patients were recruited in six centers of the German HNPCC consortium. All patients gave written informed consent for the study, approved by the ethics committees.

94 CRC patients (51 males, 43 females, mean age 45.5 , SD 33.5 years) with IHC loss of MLH1 expression and MSI-H tumours were included in this study. Of those, 16 fulfilled the Amsterdam criteria and the others met at least one of the revised Bethesda criteria. Tumour localisation was right-sided (proximally of the splenic flexure) in $75 \%$ of the cases. The BRAF mutation p.V600E which is associated with sporadic MLH1 inactivation via methylation was excluded in the tumours of all 27 patients available. $^{28}$

DNA from peripheral blood cells was extracted using the Flexigene kit (Qiagen), DNA from buccal mucosa was extracted using the QIAamp DNA Blood Mini kit (Qiagen). DNA extraction of tumour tissue and normal

a

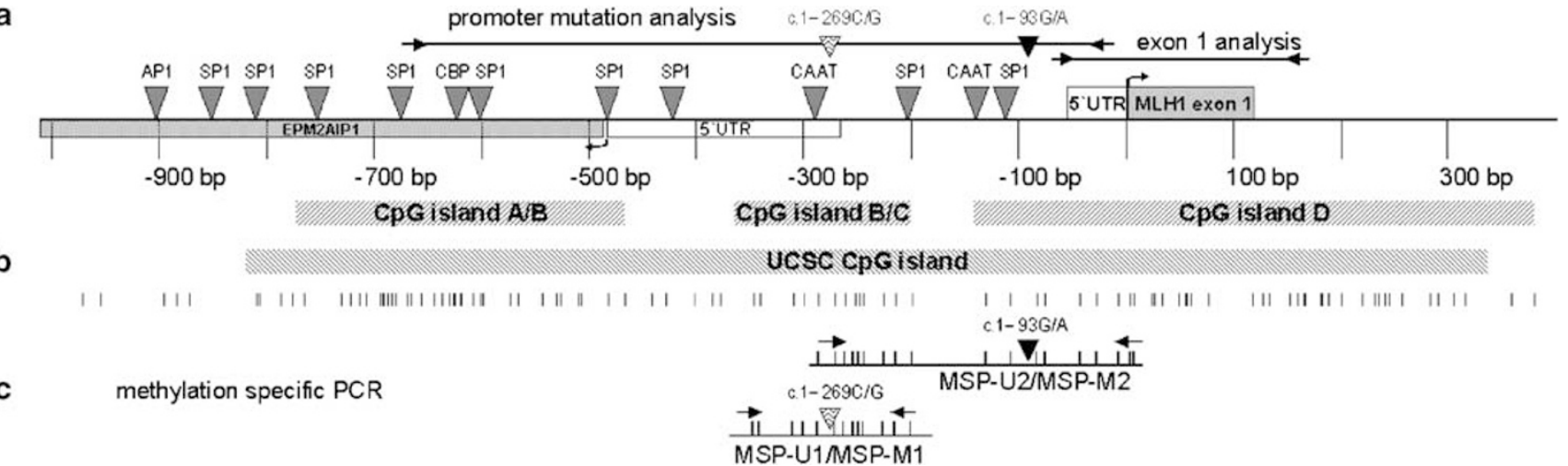

Figure 1 Promoter region of the MLH1 gene. (a) Genomic region of MLH1 and EPM2AIP1 with translation start sites (bowed arrows), coding regions (filled boxes), promoter and transcription factor-binding sites. The black lines above represent fragments used for mutation analysis and show the localisation of two SNPs. (b) Prediction of three CpG islands with prediction programs MethPrimer and EMBOSS CpGplot (depicted in grey bars) or, alternatively, one large CpG island by the UCSC software. (c) Localisation of methylation-specific primers for amplification of bisulphite-converted DNA. CpG dinucleotides are presented as vertical bars. Base positions are given relative to the MLH1 translation start site. 
tissue from paraffin-embedded material was done by microdissection. $^{29}$

\section{Microsatellite analyses and immunohistochemical staining \\ MSI-analysis and IHC-staining was done as described., ${ }^{40}$}

\section{Mutation and deletion screening of the MLH1 gene and promoter}

Mutation screening of the MLH1 gene was done by DHPLC analyses $^{31}$ or by direct sequencing. Deletion or duplication analysis of the MLH1 and MSH2 gene with an MLPA assay was published previously. ${ }^{32}$

The MLH1 core promoter is located between c.1-300 and c.1-140 bp. ${ }^{15,16,33}$ For amplification and sequencing of the region including c.1-667 to c.1-26bp (Figure 1a and Supplementary Table 1), a standard touchdown PCR protocol $^{34}$ was performed.

\section{Bisulphite treatment and methylation analyses}

Sodium bisulphite treatment was performed as published, $^{35}$ followed by methylation status-specific PCR (MSP) (Figure 1c). ${ }^{34,36}$ The MSP primer pairs for either methylated (MSP-M1/MSP-M2) or unmethylated (MSP-U1/ MSP-U2) templates in CpG islands $\mathrm{D}$ and $\mathrm{B} / \mathrm{C}$ were designed to match for bisulphite-converted DNA covering 2-3 CpG dinucleotides (Figure 1c and Supplementary Table 1). After amplification, sequencing of MSP-M1 and MSP-M2 was performed.

\section{MS-MLPA}

The methylation-specific multiplex ligation-dependent probe amplification (MS-MLPA kit ME011) method can quantify $\mathrm{CpG}$ methylation in five different $\mathrm{CpG}$-dinucleotides in the $M L H 1$ promoter (c.1-637, c.1-401, c.1-244/-250, c.1-7, c. $166+105 \mathrm{bp}$, control probe c.1-517bp). In MSMLPA, the ligation of MLPA probes is combined with digestion of the genomic DNA with the methylationsensitive endonuclease HhaI and calculated against the undigested MLPA essay. ${ }^{37,38}$

\section{cDNA expression analysis}

Total RNA was extracted from peripheral blood by the PAX Gene Blood RNA and preparation kit (PreAnalytix), cDNA was generated with the first-strand cDNA-Synthesis kit (Amersham Biosciences). ${ }^{35}$ Analysis of SNP rs1799977 in exon 8 was performed with cDNA primers $7 / 8$ forward and 9reverse (Supplementary Table 1 ) in a standard procedure ${ }^{34}$ followed by sequencing.

\section{Haplotype analyses}

To determine the haplotypes 4 markers D3S1260, D3S1283, D3S3518, and D3S1611 and SNPs rs1800734, rs35032294, and rs1799977 were investigated in DNA of all family members available.
Primer sequences are available in the Supplementary Table 1 or upon request.

\section{Results}

The study cohort consisted of 94 unrelated Bethesdapositive patients with MSI-H tumours, loss of MLH1 protein expression and a negative result in mutation- and deletion-screening in MLH1. The BRAF mutation p.V600E, frequently associated with sporadic MLH1 methylation, was excluded in the tumours available from 27 patients, including patients $1,2,3,4$, and 12 of Table 1 .

\section{Sequence analysis of the $M L H 1$ promoter}

Potential transcription factor-binding sites are located in a region of up to c.1-900 bp according to TESS (www.cbil. upenn.edu/cgi-bin/tess/tess) (Figure 1). To screen for functional mutations in the MLH1 promoter, sequence analysis of a fragment from c. $1-667$ to c. $1-26 \mathrm{bp}$ relative to the translation start of MLH1 was performed. The heterozygous sequence alteration rs35032294 at c.1-269C $>\mathrm{G}^{18}$ was found in individual 6 (Table 1). A common SNP rs $1800734^{39}$ at c.1-93G/A relative to the translation start site of MLH1, was found to be heterozygote in 41 cases (44\%), homozygote A in 11 cases (12\%) and homozygote G in 41 cases (44\%). 90 control individuals showed an allelic distribution for the SNP c.1-93G/A similar to that of our HNPCC cohort, 3\% showed the heterozygote c.1-269C/G SNP.

\section{CpG island prediction}

Analysis of the MLH1 promoter with the prediction programs MethPrimer $^{40}$ and EMBOSS CpGplot ${ }^{41}$ resulted in three CpG-islands depicted in grey boxes in Figure $1 \mathrm{~b}$. Alternatively, one large $\mathrm{CpG}$ island of $1128 \mathrm{bp}$ was described by the UCSC Genome Browser. ${ }^{42}$

CpG islands D and B/C, both downstream of c.1-500 bp are unmethylated in normal cells. ${ }^{7,43}$ Abnormal methylation of these $\mathrm{CpG}$ dinucleotides causes transcriptional silencing, whereas in the upstream CpG island A/B (c.1755 to c. $1-574 \mathrm{bp}$ ), methylation is not relevant for MLH1 transcription regulation. $5,7,43$

\section{Methylation analysis of bisulphite-converted DNA}

Screening for methylation in the functionally important regions of the $M L H 1$ promoter, which includes CpG islands $\mathrm{D}$ and $\mathrm{B} / \mathrm{C}$ (Figure 1b), identified 12 individuals (13\%) with a strong amplification of MSP-M1 and MSP-M2 (Figure 1c), indicating an aberrant $M L H 1$ promoter methylation in peripheral blood cells in these patients. Sequence analyses of MSP-M1 and MSP-M2 showed complete methylation of all 22 CpG dinucleotides (Figure 1c). Sequences of MSP-U1 and MSP-U2 did not reveal any methylation.

Seven methylation-positive patients were heterozygous in the promoter SNP c.1-93G/A or in the SNP c.1-269G/A and allowed an allelic differentiation (Table 1, patients 1, 5, 
Table 1 Results of mutation and methylation analyses in the $M L H 1$ promoter region

\begin{tabular}{|c|c|c|c|c|c|c|c|c|c|}
\hline $\begin{array}{l}\text { number } \\
\text { gender }\end{array}$ & $\begin{array}{l}\text { Age at diagnosis } \\
\text { of tumour }\end{array}$ & $\begin{array}{l}\text { Affected family } \\
\text { member (age) }\end{array}$ & $\begin{array}{l}\text { MLH1 coding } \\
\text { SNP }\end{array}$ & $\begin{array}{l}\text { MLH1 promoter } \\
\text { sequencing }\end{array}$ & $\begin{array}{l}\text { MSP-U1/MSP-U2 } \\
\text { sequencing }\end{array}$ & $\begin{array}{l}\text { MSP-M1/MSP- } \\
\text { M2 sequencing }\end{array}$ & $\begin{array}{l}\text { Methylation in } \\
\text { other tissue }\end{array}$ & $\begin{array}{l}C D N A \\
\text { expression }\end{array}$ & Methylation status \\
\hline 1 Male & $\begin{array}{l}33 \text { Ascending c } \\
47 \text { Sigmoid c } \\
47 \text { Rectum }\end{array}$ & $\begin{array}{l}\text { Brother gastric } \\
51\end{array}$ & c $655 \mathrm{G} / \mathrm{A}$ & c $1-93 \mathrm{G} / \mathrm{A}$ & $\begin{array}{l}\text { U1 NI } \\
\text { U2 c 1-93G } \\
\text { monoallelic }\end{array}$ & $\begin{array}{l}\text { M1 NI } \\
\text { M2 c 1-93A } \\
\text { monoallelic }\end{array}$ & $\begin{array}{l}\text { Colon mucosa, } \\
\text { tumour }\end{array}$ & $\begin{array}{l}\text { Complete } \\
\text { silencing of } \\
\text { MLH1 c 655A }\end{array}$ & $\begin{array}{l}\text { Clonal methylation } \\
\text { in different tissues }\end{array}$ \\
\hline 2 Female & $\begin{array}{l}58 \text { Sigmoid c } \\
59 \text { Transversal c }\end{array}$ & $\begin{array}{l}\text { Son hyperplastic } \\
\text { polyp } 34\end{array}$ & None & c $1-93 \mathrm{G} / \mathrm{G}$ & $\begin{array}{l}\text { U1 NI } \\
\text { U2 NI }\end{array}$ & $\begin{array}{l}\text { M1 NI } \\
\text { M2 NI }\end{array}$ & $\begin{array}{l}\text { Buccal, colon } \\
\text { mucosa, tumour }\end{array}$ & NI & $\begin{array}{l}\text { Clonal methylation } \\
\text { in different tissues }\end{array}$ \\
\hline 3 Male & 41 Rectum & $\begin{array}{l}\text { Mother CC } 59 \\
\text { brother polyps } 44\end{array}$ & None & c $1-93 \mathrm{G} / \mathrm{G}$ & $\begin{array}{l}\text { U1 NI } \\
\text { U2 NI }\end{array}$ & $\begin{array}{l}\text { M1 NI } \\
\text { M2 NI }\end{array}$ & $\begin{array}{l}\text { Buccal, colon } \\
\text { mucosa, tumour }\end{array}$ & NI & $\begin{array}{l}\text { Methylation in } \\
\text { different tissues }\end{array}$ \\
\hline 4 Male & 39 Transversal c & Father polyps 50 & None & c $1-93 \mathrm{G} / \mathrm{G}$ & $\begin{array}{l}\text { U1 NI } \\
\text { U2 NI }\end{array}$ & $\begin{array}{l}\text { M1 NI } \\
\text { M2 NI }\end{array}$ & - & NI & Not defined \\
\hline 5 Female & $\begin{array}{l}40 \text { Rectum } \\
41 \text { sigmoid c }\end{array}$ & $\begin{array}{l}\text { Mother } \\
\text { cervical } 33 \text { CC } 64\end{array}$ & None & c $1-93 \mathrm{G} / \mathrm{A}$ & $\begin{array}{l}\text { U1 NI } \\
\text { U2 c 1-93A } \\
\text { monoallelic }\end{array}$ & $\begin{array}{l}\text { M1 NI } \\
\text { M2 c 1-93G } \\
\text { monoallelic }\end{array}$ & - & NI & $\begin{array}{l}\text { Clonal methylation } \\
\text { in blood }\end{array}$ \\
\hline 6 Male & $\begin{array}{l}40 \text { Ascending c } 44 \\
\text { Rectum }\end{array}$ & Father polyps 50 & None & c $1-269 \mathrm{C} / \mathrm{G}$ & $\begin{array}{l}\mathrm{U} 1 \text { c } 1-269 \mathrm{C}>\mathrm{T} \\
\text { monoallelic U2 } \\
\text { NI }\end{array}$ & $\begin{array}{l}\text { M1 c 1-269G } \\
\text { monoallelic } \\
\text { M2 NI }\end{array}$ & - & NI & $\begin{array}{l}\text { clonal methylation } \\
\text { in blood }\end{array}$ \\
\hline 7 Male & 33 Transversal c & & None & c $1-93 \mathrm{G} / \mathrm{A}$ & $\begin{array}{l}\text { U1 NI } \\
\text { U2 c 1-93A } \\
\text { monoallelic }\end{array}$ & $\begin{array}{l}\text { M1 NI } \\
\text { M2 c 1-93G } \\
\text { monoallelic }\end{array}$ & - & - & $\begin{array}{l}\text { Clonal methylation } \\
\text { in blood }\end{array}$ \\
\hline 8 Male & $\begin{array}{l}35 \text { Ascending c } \\
42+48 \text { Skin } \\
49 \text { Cyst seb gland }\end{array}$ & $\begin{array}{l}\text { Uncle CC } 72 \\
\text { grandmother } \\
\text { CC } 84\end{array}$ & c $655 \mathrm{G} / \mathrm{A}$ & c $1-93 \mathrm{G} / \mathrm{G}$ & $\begin{array}{l}\text { U1 NI } \\
\text { U2 NI }\end{array}$ & $\begin{array}{l}\text { M1 NI } \\
\text { M2 NI }\end{array}$ & - & $\begin{array}{l}\text { partial } \\
\text { silencing } \\
\text { of MLH1 } \\
\text { c } 655 \mathrm{G}\end{array}$ & $\begin{array}{l}\text { Mosaic methylation } \\
\text { in blood }\end{array}$ \\
\hline 9 Female & 37 Ascending c & Father renal 41 & None & c $1-93 \mathrm{G} / \mathrm{A}$ & $\begin{array}{l}\text { U1 NI } \\
\text { U2 c 1-93 A/G } \\
\text { biallelic }\end{array}$ & $\begin{array}{l}\text { M1 NI } \\
\text { M2 c 1-93G } \\
\text { monoallelic }\end{array}$ & - & NI & $\begin{array}{l}\text { Mosaic methylation } \\
\text { in blood }\end{array}$ \\
\hline 10 Female & 30 Left flexure & & None & c $1-93 \mathrm{G} / \mathrm{A}$ & $\begin{array}{l}\text { U1 NI } \\
\text { U2 c 1-93G } \\
\text { monoallelic }\end{array}$ & $\begin{array}{l}\text { M1 NI } \\
\text { M2 c 1-93A } \\
\text { monoallelic }\end{array}$ & - & NI & $\begin{array}{l}\text { Clonal methylation } \\
\text { in blood }\end{array}$ \\
\hline 11 Male & $\begin{array}{l}46 \text { Ascending c } \\
46 \text { Transversal c }\end{array}$ & & None & c $1-93 \mathrm{~A} / \mathrm{A}$ & $\begin{array}{l}\text { U1 NI } \\
\text { U2 NI }\end{array}$ & $\begin{array}{l}\text { M1 NI } \\
\text { M2 NI }\end{array}$ & - & NI & Not defined \\
\hline 12 Female & 35 Ascending c & & c $655 \mathrm{G} / \mathrm{A}$ & c $1-93 \mathrm{G} / \mathrm{A}$ & $\begin{array}{l}\text { U1 NI } \\
\text { U2 c 1-93A/G } \\
\text { biallelic }\end{array}$ & $\begin{array}{l}\text { M1 NI } \\
\text { M2 c 1-93G } \\
\text { monoallelic }\end{array}$ & - & - & $\begin{array}{l}\text { Mosaic methylation } \\
\text { in blood }\end{array}$ \\
\hline
\end{tabular}

Abbreviations: $\mathrm{CC}$, colon cancer; c, colon; Cyst seb, cystic sebaceous; NI, not informative; - , no material available.

Of 94 HNPCC-suspected MLH1 mutation-negative patients with MSI-H and loss of MLH1 protein expression in their tumours, 12 patients were methylation-positive.

7, 9, 10, 12). Sequencing of MSP-M2 showed only one allele, either G (four cases) or A (two cases), indicating an allele-specific methylation, which is not restricted to either the G- or A-allele. MSP-U2 represented exclusively the other allele in four cases (Table 1 , patients $1,5,7,10$, Figure $2 \mathrm{a}$ ) but was still heterozygous in two cases (Table 1, patients 9 and 12, Figure 2b). This finding denotes an allele-specific methylation, which might not be complete in all hematopoietic cells - indicating a mosaic methylation pattern in two patients.

Patient 6, carrying the heterozygous sequence alteration c.1-269C > G, showed a complete and allele-specific methylation of only the variant c.1-269G allele in MSP-M1, while
MSP-U1 monoallelically represented the c.1-269C allele (Table 1).

Methylation was also found in buccal mucosa and normal colonic tissue in three methylation-positive cases analysed. Analysis of the tumour tissues of these patients also revealed methylated and unmethylated alleles. No methylation of the MLH1 promoter was found in 82 patients and 75 healthy control subjects.

The methylation-specific multiplex ligation-dependent probe amplification (MS-MLPA ME011) assay was used for quantification of aberrant methylation in single CpG-dinucleotides in the MLH1 promoter, data are displayed in detail in Supplementary Figure 2. The average 


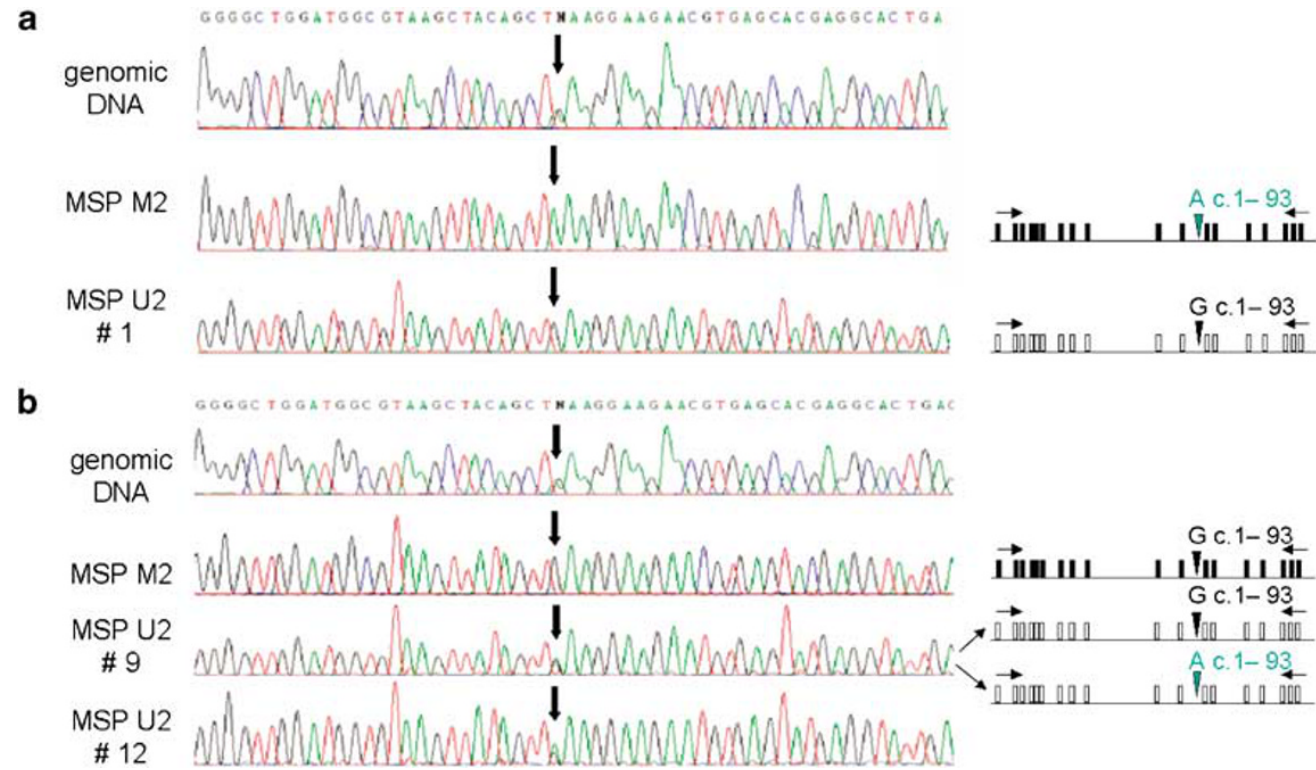

Figure 2 Bisulphite sequences of the methylated fragments revealed allele-specific methylation in all seven genomically heterozygous patients allowing allelic discrimination by promoter SNPs. Five cases showed complete methylation profiles by monoallelic presentation also in the unmethylated fragment $(\mathbf{a})$. However, in two patients $(9,12)$ the methylation of the G-allele was incomplete, as the unmethylated fragment represented two alleles (b).
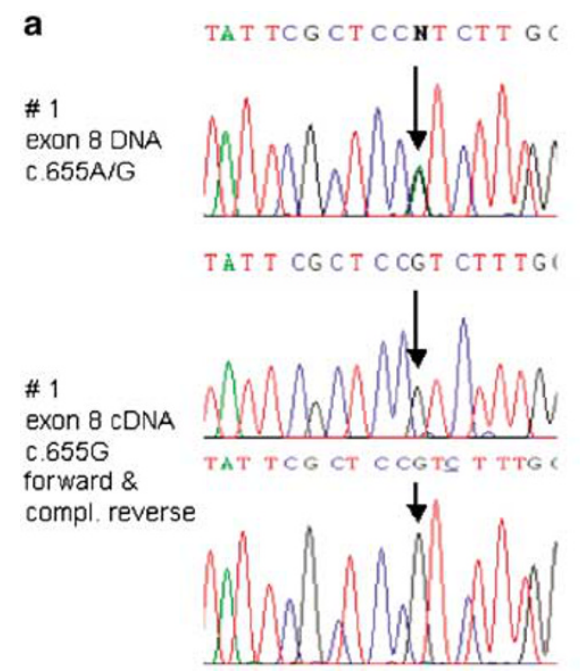

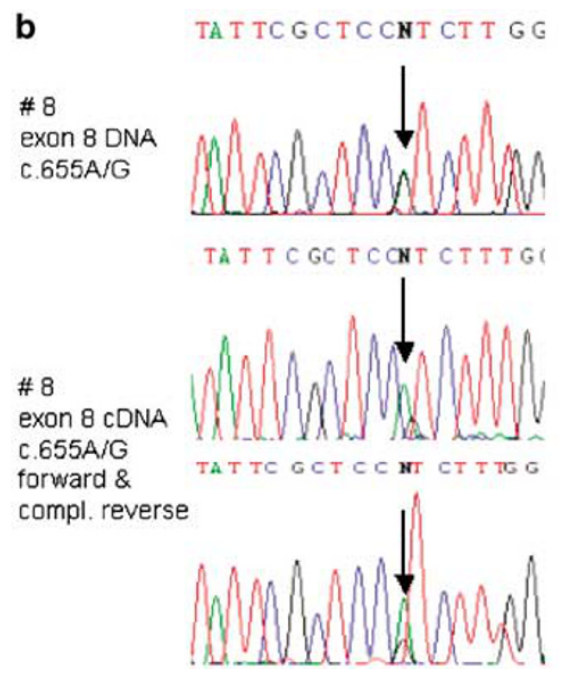

b

\# 8

exon 8 DNA

c.655A/G

Figure 3 Allelic expression of $M L H 1$ in two methylation-positive patients genomically heterozygous in MLH1 exon 8 (top lanes). Bottom lanes: CDNA sequences showed monoallelic expression of the c.655G-allele and complete transcriptional silencing of the c.655A-allele in patient 1 (a). Only partial silencing was found in patient 8 (b) showing a significant expression reduction of the c.655G-allele.

percentage of methylation was $45-55 \%$ in the five patients $(1,5,6,7$, and 10$)$ with complete methylation of one allele found by allele-specific sequencing of promoter SNPs. For those three patients $(8,9$, and 12$)$ with supposed mosaic methylation, MS-MLPA analysis revealed methylation of 19-31\% supporting our previous data. The data for four patients without SNPs revealed full methylation in patient 2 and methylation of $10-20 \%$ in patients 3, 4, 11 and the mother of patient 4 , which are therefore also assumed to be mosaic.

\section{MLH1 cDNA expression}

The allelic expression of MLH1 cDNA was analysed in two methylation-positive patients, both heterozygous for the SNP (c.655A>G; I219V; rs1799977) in MLH1 exon 8. CDNA-sequencing detected a monoallelical expression of the c.655G allele of MLH1 for patient 1 (Figure 3a), indicating a complete transcriptional silencing of the c.655A allele, whereas patient 8 showed a signal reduction of approximately 50\%, indicating an incomplete transcriptional silencing of the c.655G allele (Figure 3b). 


\section{Family studies}

Blood samples of eight first degree relatives of five methylation carriers revealed methylation in the MLH1 promoter in one case (for details see Supplementary Figure 1 ). The mother of patient 4 showed methylation in blood cells and no external hint to be affected at age 64 but was sent to colonoscopy.

For patient 3, the methylation could not be linked to one allele but his three healthy sons inherited different paternal alleles and were all methylation negative. The methylated allele of patient 9 was derived from her healthy mother who is methylation negative. The son of patient 6 showed no methylation but had inherited the allele unmethylated in his father.

The methylated allele of patient 5 was inherited from her affected mother (cervical cancer at age 33, colon cancer at age 64 without MSI and without loss of MMR protein expression in the CRC), but in the mother the allele was unmethylated. The healthy brother had an unmethylated MLH1 promoter and did not carry the allele methylated in his sister.

Clinical phenotypes of methylation-positive patients The clinical phenotypes of the patients are summarised in Table 1 . None of the 12 methylation-positive patients fulfilled the Amsterdam criteria, but four patients had one or two family members with gastrointestinal malignancies (Table 1). Eight CRCs were right-sided (proximal to the splenic flexure) and four left-sided primary tumours. Synor metachronous CRCs were diagnosed in 50\% of the patients. The mean age at tumour diagnosis was $39 \pm 19$ years SD.

\section{Discussion}

We report the so far largest cohort of unrelated HNPCCsuspected individuals with hypermethylation of the proximal promoter region of the $M L H 1$ gene in peripheral blood cells. This doubles the number of cases reported to date. $^{22-27}$

Seven of the 12 patients had promoter SNPs, which enabled us to prove allele-specific hemiallelic methylation in peripheral blood cells (mesodermal). For three patients endodermal tissues (colonic or buccal mucosa) were available and also methylation-positive. A pan-cellular, allele-specific hypermethylation of the MLH1 promoter in different germ cell lineages was previously described for nine patients. ${ }^{22-27}$ Monoallelic MLH1 expression could be shown in one of our patients, which was also found in three cases in the literature. ${ }^{22,24,27}$

For the first time, we report two patients with evidence of a mosaic methylation pattern on one allele for the MLH1 promoter using a SNP at position c.1-93. This incomplete methylation might be due to a clonal expansion of methylated and unmethylated cells, or to a loss or gain of methylation as a somatic event in hematopoietic cells. One further patient revealed an incomplete silencing of a coding SNP in cDNA exon 8, again indicating an inconsistent methylation pattern. The results of methylation extent gained by methylation-specific multiplex ligation-dependent probe amplification (MSMLPA) supported our previous findings by MSP-sequencing. Further three patients without SNPs analysed by MS-MLPA revealed a mosaic methylation pattern. A possible explanation might be a de novo methylation event after fertilisation, which leads to a clonal or mosaic methylation.

Furthermore, we could show in three patients that inactivation of the second allele in the tumour tissue is due to a mechanism independent of methylation, as no methylation for the second allele was detectable in the three tumour tissues analysed.

Methylation is an epigenetic modification of the DNA which is passed on in somatic mitosis, but it is reversible, considering the comprehensive remodification processes of genomic methylation that occur between primordial germ cell formation and the preimplantation embryo. ${ }^{44-46}$

The family history of methylation carriers was negative in eight of our cases as well as in nine of 11 cases reported in the literature. ${ }^{22,24,25}$ Inheritance was analysed in literature in 11 families, but so far only in one family a maternal transmission of the methylation in the MLH1 promoter could be proven. ${ }^{22,24,27}$ For the patients studied here, we were able to analyse inheritance in eight family members. The finding of MLH1 promoter methylation in a mother and her son implicates a maternal transmission of methylation, while methylation erasure was found in the three methylation negative sons with different paternal alleles of a methylation-positive father. In two families a de novo set up of methylation in maternal alleles was found. One daughter had a mosaic or incomplete methylation, while the daughter of the other family showed a complete methylation of the de novo methylated allele.

We suspect a methylation event by chance without familial segregation and a low risk of transmission as four allele-sharing siblings published previously and six family members described here, were discordant in respect to MLH1 promoter methylation. ${ }^{22,27}$

Strikingly, we found incomplete methylation (8\%) in the 64-year-old mother of patient 4 (10\% methylation) hinting towards a heritable predisposition to an epimutation in MLH1 eventually due to (1) a maternally transmitted germline methylation or (2) a methylation-inducing mechanism in cis caused by the genetic environment.

A striking transmission of mosaic methylation in the promoter of $\mathrm{MSH} 2$ has been reported in one family over three generations and further investigations are necessary to clarify the cause of inheritance of only mosaic and low-level methylation in blood. ${ }^{47}$ Here, one could argue for a possible partial erasure of methylation in highly 
proliferative cells, accompanied by a consistent methylation in germ cells. We could not find mosaic and lowlevel methylation in blood of siblings.

Nevertheless, the negative or weak family history in the majority of our cases, the consideration that six patients display a mosaic methylation in hematopoietic cells and the fact that de novo methylation was shown in two cases, underlines that inheritance of a predisposition to an epimutation for MLH1 promoter hypermethylation is a rare event. The erasure of methylation in gametogenesis found in the sons of methylation-carrier 3 is supported by methylation patterns of either 0 or $1 \%$ in the spermatozoa of two methylation carriers. ${ }^{22}$ The incomplete erasure of methylation (1\%) might be an artefact as well. ${ }^{48}$

CpG islands of some genes, among them MLH1, are more prone to methylation in several types of cancers. ${ }^{7,9,11,49}$ In this respect it is noteworthy that the methylated alleles traced back were of maternal origin in three cases in the literature ${ }^{24,27}$ and in one case published here. An increased maternal age at pregnancy can be excluded, as all pregnancies came prior to a maternal age of 34 years, as well as methylation errors due to assisted reproductive techniques.

The clinical phenotypes of 12 MLH1 methylationpositive cases described here are similar to patients with pathogenic MLH1 germline mutations. ${ }^{50,51}$ The mean age of tumour onset was 39 years (range 30-58 years), however, we found a high incidence of syn-/metachronous tumours in $50 \%$. In the current literature of MLH1 promoter methylation cases ${ }^{22-27}$ clinical features of 11 patients revealed a mean age of onset of 32 years (range 17-46 years) and syn-/metachronous disease in 50\%. The clinical features of the six patients with a mosaic methylation pattern did not differ and were not in any sense milder; one showed the Muir-Torre phenotype and was 35 years old at tumour manifestation, the others were 35,37 , 39,41 and 46 years old at tumour manifestation.

There is increasing evidence that aberrant methylation in the promoter region of one $M L H 1$ allele is functionally equivalent to a pathogenic $M L H 1$ germline mutation and mimics the clinical phenotype of Lynch syndrome. To which extent the tumour risk is influenced by the mosaic methylation has to be determined. With the few data we have generated here, there is no difference in age of onset in correlation to the methylation status, mosaic or not mosaic, in blood cells. Nevertheless, there is increasing evidence that these seemingly 'sporadic' HNPCC-patients need to be treated the same way as Lynch syndrome patients in regard to clinical aspects.

Of all patients with specified pre-lesion in the MLH1 gene 2\% have an aberrant MLH1 promoter methylation in their normal cells, the others are carriers of pathogenic germline point mutations or deletions in MLH1. Aberrant methylation of promoters has hitherto been rarely found and investigated, but in the thus far largest cohort analysed constitutes $13 \%$ of patients with suspected
HNPCC-syndrome without MLH1 germline mutation but with MLH1-deficient and MSI-H tumours. Therefore, methylation analysis of the MLH1 promoter should be performed for all early-onset or multiple colorectal cancer patients with MSI-H tumours, and loss of IHC MLH1 protein expression of unknown cause. At least first degree relatives of methylation-positive should be offered the MLH1 promoter methylation analysis to exclude the rare event of inheritance of a familial epimutation, as found in one of our cases.

\section{Acknowledgements}

This work was supported by the Wilhelm-Sander Foundation and the German Cancer Aid (Mildred-Scheel Foundation). Professor M Ebert was supported by the BMWi/AIF and Else-Kröner-Foundation. We thank Trisari Massdorf and Cortina Keiling for their reliable technical assistance.

\section{Ethics approval}

Local ethics committees of all university hospitals involved in the study approved the study protocol.

\section{Conflict of interest}

Authors and co-authors declare that there are no competing interests related to the presented article.

\section{References}

1 Lynch HT, de la Chapelle A: Genetic susceptibility to nonpolyposis colorectal cancer. J Med Genet 1999; 36: 801-818.

2 Vasen HF, Mecklin JP, Khan PM, Lynch HT: The International Collaborative Group on Hereditary Non-Polyposis Colorectal Cancer (ICG-HNPCC). Dis Colon Rectum 1991; 34: 424-425.

3 Vasen HF, Watson P, Mecklin JP, Lynch HT: New clinical criteria for hereditary nonpolyposis colorectal cancer (HNPCC, Lynch syndrome) proposed by the International Collaborative Group on HNPCC. Gastroenterology 1999; 116: 1453-1456.

4 Boland CR, Thibodeau SN, Hamilton SR et al: A National Cancer Institute Workshop on microsatellite instability for cancer detection and familial predisposition: development of international criteria for the determination of microsatellite instability in colorectal cancer. Cancer Res 1998; 58: 5248-5257.

5 Deng G, Chen A, Hong J, Chae HS, Kim YS: Methylation of CpG in a small region of the hMLH1 promoter invariably correlates with the absence of gene expression. Cancer Res 1999; 59: 2029-2033.

6 Constancia M, Pickard B, Kelsey G, Reik W: Imprinting mechanisms. Genome Res 1998; 8: 881-900.

7 Furukawa T, Konishi F, Masubuchi S, Shitoh K, Nagai H, Tsukamoto T: Densely methylated MLH1 promoter correlates with decreased mRNA expression in sporadic colorectal cancers. Genes Chromosomes Cancer 2002; 35: 1-10.

8 Simpkins SB, Bocker T, Swisher EM et al: MLH1 promoter methylation and gene silencing is the primary cause of microsatellite instability in sporadic endometrial cancers. Hum Mol Genet 1999; 8: 661-666.

9 Esteller M, Levine R, Baylin SB, Ellenson LH, Herman JG: MLH1 promoter hypermethylation is associated with the microsatellite instability phenotype in sporadic endometrial carcinomas. Oncogene 1998; 17: 2413-2417.

10 Burgart LJ: Testing for defective DNA mismatch repair in colorectal carcinoma: a practical guide. Arch Pathol Lab Med 2005; 129: $1385-1389$.

11 Suzuki H, Itoh F, Toyota $\mathrm{M}$ et al: Distinct methylation pattern and microsatellite instability in sporadic gastric cancer. Int J Cancer 1999; 83: 309-313. 
12 Kuismanen SA, Holmberg MT, Salovaara R, de la Chapelle A, Peltomaki P: Genetic and epigenetic modification of MLH1 accounts for a major share of microsatellite-unstable colorectal cancers. Am J Pathol 2000; 156: 1773-1779.

13 Kane MF, Loda M, Gaida GM et al: Methylation of the hMLH1 promoter correlates with lack of expression of hMLH1 in sporadic colon tumors and mismatch repair-defective human tumor cell lines. Cancer Res 1997; 57: 808-811.

14 Herman JG, Umar A, Polyak $\mathrm{K}$ et al: Incidence and functional consequences of hMLH1 promoter hypermethylation in colorectal carcinoma. Proc Natl Acad Sci USA 1998; 95: 6870-6875.

15 Quaresima B, Faniello MC, Baudi F et al: Transcriptional regulation of the mismatch repair gene hMLH1. Gene 2001; 275: $261-265$

16 Warnick CT, Dabbas B, Ilstrup SJ, Ford CD, Strait KA: Cell typedependent regulation of hMLH1 promoter activity is influenced by the presence of multiple redundant elements. Mol Cancer Res 2003; 1: 610-618.

17 Shin KH, Shin JH, Kim JH, Park JG: Mutational analysis of promoters of mismatch repair genes hMSH2 and hMLH1 in hereditary nonpolyposis colorectal cancer and early onset colorectal cancer patients: identification of three novel germ-line mutations in promoter of the hMSH2 gene. Cancer Res 2002; 62: $38-42$.

18 Zavodna K, Bujalkova M, Krivulcik T et al: Novel and recurrent germline alterations in the MLH1 and MSH2 genes identified in hereditary nonpolyposis colorectal cancer patients in Slovakia. Neoplasma 2006; 53: 269-276.

19 Toyota M, Ahuja N, Ohe-Toyota M, Herman JG, Baylin SB, Issa JP: CpG island methylator phenotype in colorectal cancer. Proc Natl Acad Sci USA 1999; 96: 8681-8686.

20 Issa JP: The epigenetics of colorectal cancer. Ann N Y Acad Sci 2000; 910: 140-153; discussion 153-155.

21 Issa JP, Shen L, Toyota M: CIMP, at last. Gastroenterology 2005; 129: $1121-1124$.

22 Suter CM, Martin DI, Ward RL: Germline epimutation of MLH1 in individuals with multiple cancers. Nat Genet 2004; 36: 497-501.

23 Miyakura Y, Sugano K, Akasu T et al: Extensive but hemiallelic methylation of the hMLH1 promoter region in early-onset sporadic colon cancers with microsatellite instability. Clin Gastroenterol Hepatol 2004; 2: 147-156.

24 Hitchins M, Williams R, Cheong $\mathrm{K}$ et al: MLH1 germline epimutations as a factor in hereditary nonpolyposis colorectal cancer. Gastroenterology 2005; 129: 1392-1399.

25 Gazzoli I, Loda M, Garber J, Syngal S, Kolodner RD: A hereditary nonpolyposis colorectal carcinoma case associated with hypermethylation of the MLH1 gene in normal tissue and loss of heterozygosity of the unmethylated allele in the resulting microsatellite instability-high tumor. Cancer Res 2002; 62: $3925-3928$.

26 Valle L, Carbonell P, Fernandez V et al: MLH1 germline epimutations in selected patients with early-onset non-polyposis colorectal cancer. Clin Genet 2007; 71: 232-237.

27 Hitchins MP, Wong JJ, Suthers G et al: Inheritance of a cancerassociated MLH1 germ-line epimutation. N Engl J Med 2007; 356: $697-705$.

28 Deng G, Bell I, Crawley $\mathrm{S}$ et al: BRAF mutation is frequently present in sporadic colorectal cancer with methylated hMLH1, but not in hereditary nonpolyposis colorectal cancer. Clin Cancer Res 2004; 10: 191-195.

29 Mueller-Koch Y, Vogelsang H, Kopp R et al: Hereditary non-polyposis colorectal cancer: clinical and molecular evidence for a new entity of hereditary colorectal cancer. Gut 2005; 54: $1733-1740$.

30 Dietmaier W, Wallinger S, Bocker T, Kullmann F, Fishel R, Ruschoff J: Diagnostic microsatellite instability: definition and correlation with mismatch repair protein expression. Cancer Res 1997; 57: 4749-4756.

31 Holinski-Feder E, Muller-Koch Y, Friedl W et al: DHPLC mutation analysis of the hereditary nonpolyposis colon cancer (HNPCC) genes hMLH1 and hMSH2. J Biochem Biophys Methods 2001; 47: $21-32$.

32 Grabowski M, Mueller-Koch Y, Grasbon-Frodl E et al: Deletions account for $17 \%$ of pathogenic germline alterations in MLH1 and MSH2 in hereditary nonpolyposis colorectal cancer (HNPCC) families. Genet Test 2005; 9: 138-146.

33 Deng G, Chen A, Pong E, Kim YS: Methylation in hMLH1 promoter interferes with its binding to transcription factor CBF and inhibits gene expression. Oncogene 2001; 20: 7120-7127.

34 Don RH, Cox PT, Wainwright BJ, Baker K, Mattick JS: Touchdown PCR to circumvent spurious priming during gene amplification. Nucleic Acids Res 1991; 19: 4008.

35 Grabowski M, Zimprich A, Lorenz-Depiereux B et al: The epsilonsarcoglycan gene (SGCE), mutated in myoclonus-dystonia syndrome, is maternally imprinted. Eur J Hum Genet 2003; 11: $138-144$.

36 Kosaki K, McGinniss MJ, Veraksa AN, McGinnis WJ, Jones KL: Prader-Willi and Angelman syndromes: diagnosis with a bisulfitetreated methylation-specific PCR method. Am J Med Genet 1997; 73: $308-313$.

37 Nygren AO, Ameziane N, Duarte HM et al: Methylation-specific MLPA (MS-MLPA): simultaneous detection of CpG methylation and copy number changes of up to 40 sequences. Nucleic Acids Res 2005; 33: e128.

38 Jeuken JW, Cornelissen SJ, Vriezen $\mathrm{M}$ et al: MS-MLPA: an attractive alternative laboratory assay for robust, reliable, and semiquantitative detection of MGMT promoter hypermethylation in gliomas. Lab Invest 2007; 87: 1055-1065.

39 Ito E, Yanagisawa Y, Iwahashi $\mathrm{Y}$ et al: A core promoter and a frequent single-nucleotide polymorphism of the mismatch repair gene hMLH1. Biochem Biophys Res Commun 1999; 256: 488-494.

40 Li LC, Dahiya R: MethPrimer: designing primers for methylation PCRs. Bioinformatics 2002; 18: 1427-1431.

41 Rice P, Longden I, Bleasby A: EMBOSS: the European Molecular Biology Open Software Suite. Trends Genet 2000; 16: 276-277.

42 Kent WJ, Sugnet CW, Furey TS et al: The human genome browser at UCSC. Genome Res 2002; 12: 996-1006.

43 Miyakura Y, Sugano K, Konishi F et al: Extensive methylation of hMLH1 promoter region predominates in proximal colon cancer with microsatellite instability. Gastroenterology 2001; 121: $1300-1309$

44 Mayer W, Niveleau A, Walter J, Fundele R, Haaf T: Demethylation of the zygotic paternal genome. Nature 2000; 403: 501-502.

45 Reik W, Walter J: Genomic imprinting: parental influence on the genome. Nat Rev Genet 2001; 2: 21-32.

46 Reik W, Walter J: Evolution of imprinting mechanisms: the battle of the sexes begins in the zygote. Nat Genet 2001; 27: 255-256.

47 Chan TL, Yuen ST, Kong CK et al: Heritable germline epimutation of $\mathrm{MSH} 2$ in a family with hereditary nonpolyposis colorectal cancer. Nat Genet 2006; 38: 1178-1183.

48 Suter CM, Martin DI, Ward RL: Addendum: germline epimutation of MLH1 in individuals with multiple cancers. Nat Genet 2007; 39: 1414.

49 Issa JP: CpG island methylator phenotype in cancer. Nat Rev Cancer 2004; 4: 988-993.

50 Mangold E, Pagenstecher C, Friedl W et al: Spectrum and frequencies of mutations in MSH2 and MLH1 identified in 1,721 German families suspected of hereditary nonpolyposis colorectal cancer. Int J Cancer 2005; 116: 692-702.

51 Goecke T, Schulmann K, Engel C et al: Genotype-phenotype comparison of German MLH1 and MSH2 mutation carriers clinically affected with Lynch syndrome: a report by the German HNPCC Consortium. J Clin Oncol 2006; 24: 4285-4292.

Supplementary Information accompanies the paper on European Journal of Human Genetics website (http://www.nature.com/ejhg) 